\title{
Biocompatibility of NGF-grafted GTG membranes for peripheral nerve repair using cultured Schwann cells
}

\author{
Pei-Ru Chen ${ }^{\mathrm{a}}$, Ming-Hong Chen ${ }^{\mathrm{a}, \mathrm{b}}$, Jui-Sheng Sun ${ }^{\mathrm{c}, \mathrm{f}}$, Mei-Hsiu Chen ${ }^{\mathrm{d}}$, Chien-Chen Tsai ${ }^{\mathrm{e}}$, \\ Feng-Huei Lin ${ }^{\mathrm{f}, *}$ \\ anstitute of Biomedical Engineering, College of Medicine, College of Engineering, National Taiwan University, No 1, Sec. 1, Jen-Ai Road, \\ Tiapei, Taiwan \\ ${ }^{\mathrm{b}}$ Division of Neurosurgery, Department of Surgery, Cathay General Hospital, Taiwan \\ ${ }^{\mathrm{c}}$ Department of Orthopedics, Yunlin Hospital, Taiwan \\ ${ }^{\mathrm{d}}$ Department of Medicine, Far Eastern Memorial Hospital, Taiwan \\ ${ }^{\mathrm{e}}$ Department of Pathology, Far Eastern Memorial Hospital, Taiwan \\ ${ }_{\mathrm{f}}^{\mathrm{f}}$ Department of Biomedical Engineering, National Taiwan University Hospital, Taiwan
}

Received 28 July 2003; accepted 16 January 2004

\begin{abstract}
We previously developed a biodegradable composite with potentially good biocompatibility composed by tricalcium phosphate and gluataraldehyde cross-linking gelatin (GTG) with good mechanical property feasible for surgical manipulation. The purpose of this study was to evaluate the feasibility of immobilizing nerve growth factor (NGF) onto the composite (GTG) with carbodiimide (GEN composite). Cultured Schwann cells were seeded onto the GTG and GEN composites. For comparison, GTG membrane soaked in NGF solution without carbodiimide (GN composite) as cross-linking agent was also used to culture Schwann cells. Cell morphology was observed by a scanning electron microscope. Cell survival, cytotoxicity and cellular metabolism on the NGFgrafted GTG membrane were assessed quantitatively in terms of cell protein content, leakage of cytosolic lactate dehydrogenase (LDH) activity and by the well-established MTT assay, respectively. The result of LDH study did not show significant difference among GTG, NGF-modified GTG and control group. This indicated that GTG composite, whether cross-linking with NGF or not, has little cytotoxic effect. Comparing the protein content and MTT assay among GEN, GN composite and control group, the data confirmed more attachment of Schwann cells on GEN composite. Although GTG cross-linking with NGF did not promote Schwann cell proliferation, the techniques we used in this study provided a method to fabricate a novel biomaterial incorporation of Schwann cells and covalently immobilized NGF.
\end{abstract}

(C) 2004 Elsevier Ltd. All rights reserved.

Keywords: Biodegradable nerve conduit; Gelatin; Schwann cell; Nerve growth factor

\section{Introduction}

In clinical practice, direct end-to-end suturing techniques are suggested for a short nerve injury. When large gaps remain between the ends of injured peripheral nerves, nerve autografting has been the first choice for repairing nerve gaps. However, this approach has inevitable disadvantages, such as limited supply of available nerve autografts and certain donor site

*Corresponding author. Tel.: +886-2-23912641; fax: +886-223940049.

E-mail address: double@ha.mc.ntu.edu.tw (F.-H. Lin). morbidity. Xenografts and allografts have been evaluated as alternatives to autografts but have poor successful rate and problems of immune rejection [1,2]. A wide range of materials has been developed for use as a synthetic nerve guidance channel [3-8]. Of these materials, nondegradable materials such as silicone rubber have been widely used because of their inert and mechanical properties. However, upon completion of regeneration these materials no longer serve any purpose and may become detrimental due to mechanical impingement or infection [9]. Contrarily, biodegradable materials potentially avoid these problems and make secondary surgery unnecessary. Biodegradable materials such as polyglycolic acid (PGA) [1] and polylactic acid 
(PLA) $[10,11]$ are used for tubulization to bridge both ends of the amputated peripheral nerve. Nonetheless, upon degradation by hydrolysis, PLA and PGA produce lactic acid and glycolic acid, respectively. These degradation by-products would lead to a lowering of local $\mathrm{pH}$ and could be detrimental to the surrounding cells and tissue $[12,13]$. Nerve guidance channels have also been fabricated out of collagen with favorable results in nerve repair $[5,14,15]$. But collagen is rather expensive and difficult to handle during suturing because of mechanical weakness. On the other hand, thermal denaturation or physical and chemical degradation of collagen gives gelatin. With respect to collagen, gelatin does not express antigenicity in physiological conditions, and it is much cheaper and easier to obtain in concentrate solutions. Besides, gelatin is a biodegradable polymer with excellent biocompatibility, plasticity and adhesiveness [16]. The use of proper cross-linking agents such as glutaraldehyde at low concentration further allows to modulate the mechanico-chemical properties of gelatin films [17].

When designing a nerve guidance channel from tissue engineering approach, besides conduit material, incorporation of neurotrophic factors and cells supporting axon regeneration should also be considered. Nerve regeneration has been shown to be enhanced across gaps utilizing guidance channels filled with neutrophic factors such as nerve growth factor (NGF), glial cell linederived neurotrophic factor (GDNF) and neurotrophin NT-3 [18-21]. On the other hand, gelatin contains primary carboxyl groups on its chain backbones which give gelatin potential to bind covalently the amine groups of these neurotrophic molecules with appropriate cross-linking agent [22-25]. We previously developed a biodegradable and biocompatible composite composed by tricalcium phosphate and gluataraldehyde cross-linking gelatin (GTG) with good mechanical property feasible for surgical manipulation. In this work, nerve-growth-factor (NGF) was immobilized onto the surface of GTG membrane (GEN). Crosslinking with a water-soluble carbodiimide led to a covalent and stable binding between the amine groups of NGF and the carboxyl groups on the surface of GTG membrane.

Besides NGFs, several studies have shown enhanced regeneration when Schwann cells were seeded within nerve guidance channels [26-30]. Therefore, we also tried to culture Schwann cells on our composite membrane. Then, biocompatibility of the composite was assessed quantitatively in terms of cell protein content, leakage of cytosolic lactate dehydrogenase (LDH) activity [31] through damaged Schwann cell membranes and by the well-established MTT assay [32]. In this study, the morphology of Schwann cells seeded on the GEN membrane and the results of in vitro biocompatibility studies suggest that our tissue engi- neered composite membrane is a promising candidate biomaterial for nerve regeneration.

\section{Materials and methods}

\subsection{GTG membrane preparation}

We prepared the matrix phase of the GTG composite by adding $22.5 \mathrm{~g}$ of bovine gelatin (Sigma Chemical Co., St. Louis, MO, USA) to $380 \mathrm{ml}$ of deionized distilled water. The mixture was stirred vigorously and kept at $70^{\circ} \mathrm{C}$ until a homogenous gelatin solution was attained. $22.5 \mathrm{~g}$ of TCP particle were then poured down into the gelatin solution. The mixture was stirred for $5 \mathrm{~min}$ to ensure a uniform consistency. In order to obtain the homogenous and higher cross-linking density of the composites, the temperature of the mixture was cooled to $35^{\circ} \mathrm{C}$, then, $22.5 \mathrm{ml} 1 \%$ glutaraldehyde solution was added for cross-linking reaction of the gelatin. After the mixtures were cross-linked, they were poured down into blank dishes and dried in an oven overnight to form membranes. The membranes were then soaked in $0.1 \%$ glutaraldehyde solution for another $8 \mathrm{~h}$ for further cross-linking. The cross-linked GTG membrane was further treated with $0.1 \mathrm{M}$ glycine aqueous solution to block non-reacted aldehyde groups, and then washed with double-distilled water. The composites were used in the later experiment for Schwann cell seeding and NGF grafting.

\subsection{NGF covalently immobilized onto GTG membrane (GEN membrane)}

To immobilize NGF (Chemicon Co., 7S NGF) onto GTG membrane, GTG membranes were soaked in $20 \mathrm{ml} 0.1 \mathrm{wt} \%$ 1-ethyl-3-(3-dimethylaminopropyl) carbodiimide (EDAC) solution for $24 \mathrm{~h}$ at $4^{\circ} \mathrm{C}$. The membranes were then transferred to $50 \mathrm{ng} / \mathrm{ml} \mathrm{NGF}$ solution for $24 \mathrm{~h}$ at $4{ }^{\circ} \mathrm{C}$. The reaction of NGF with the primary amine that existed on the surface of GTG membranes was initiated with carbodiimide. The proposed mechanism of NGF cross-linking is shown in Fig. 1. Unbound and excess chemicals were removed by washing the membranes with phosphate buffer solution (PBS).

\subsection{Cell culture}

GTG/GEN membranes were cut into circular discs suitably sized for tissue culture plate wells. The membranes were sterilized with $70 \%$ alcohol under ultraviolet light overnight and then rinsed extensively with PBS. Membranes for this experiment were divided into four groups for Schwann cell culture $(n=18)$ : (1) GTG membrane with NGF covalently immobilized 


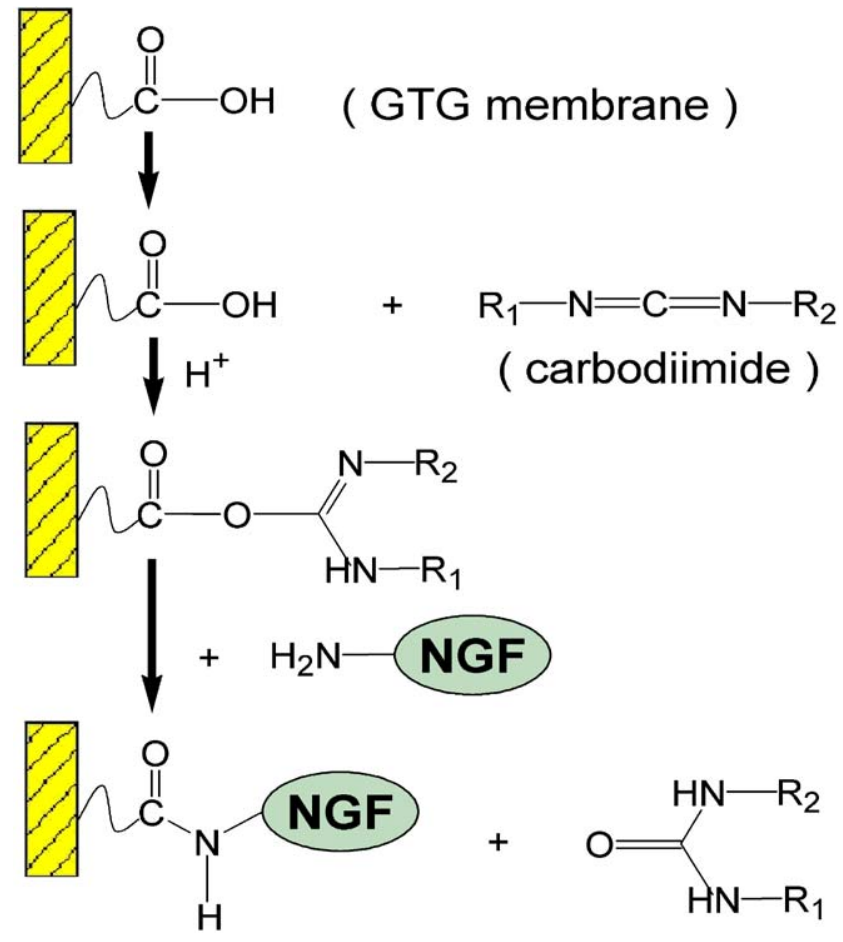

Fig. 1. The steps of cross-linking with carbodiimide led to a covalent and stable binding between the amine groups of NGF and the carboxyl groups on the surface of GTG membrane.

(GEN), (2) GTG membrane soaked in $50 \mathrm{ng} / \mathrm{dl}$ NGF solution for $24 \mathrm{~h}(\mathrm{GN})$ (washed three times with PBS before cell culture), (3) blank GTG composite (GTG), and (4) Petri dish as control group.

Schwann cells from neonatal Lewis rats were isolated and expanded in culture using methods described by Brockes et al. [33]. Briefly, 4 litters of day 2 Lewis pups were killed, and their sciatic nerve were removed. After enzymatic digestion with collagenase and dispase, the primary cell suspension was plated in Dulbecco modified Eagle medium (DMEM), enriched with 10\% heatinactivated fetal bovine serum (FBS) and antibiotic (penicillin-streptomycin solution). The cells were treated for the ensuing 2-3 days with cytosine arabinoside to inhibit the proliferation of fibroblast. On the 7th day, $0.2 \mathrm{ml} 5 \times 10^{5}$ cells $/ \mathrm{ml}$ Schwann cells were seeded in individual wells of a 24-well tissue culture plate with $2 \mathrm{ml}$ DMEM and 10\% FBS for testing the effects of various GTG composites on the growth of Schwann cells. The cultures were examined by using light microscope on a daily basis for observations of adherence, survival and proliferation.

\subsection{Morphological evaluation of Schwann cells cultured on GTG composites}

For morphological evaluation, the Schwann cells adhering to the GTG membrane were fixed with $10 \%$ formaldehyde in PBS for $24 \mathrm{~h}$. After washed with PBS, the cell seeded membrane were dehydrated through an ascending alcohol series, commencing at a solution of $70 \%$ alcohol, then dried in a critical point drier (CPD) and gold coated. All specimens were then examined by scanning electron microscope.

\subsection{Evaluation of biocompatibility of GTG membrane}

On day 1, 3, 7 after Schwann cells seeded onto composite membranes in each experimental group, biocompatibility of the composite was assessed quantitatively in terms of cell protein content, leakage of cytosolic LDH activity and by the MTT assay.

\subsubsection{Total cell protein}

Eighty microliters of $0.5 \mathrm{~m} \mathrm{NaOH}$ were added to each well, the plates were sealed and cell proteins digested at $37^{\circ} \mathrm{C}$ for $18 \mathrm{~h} .0 .2 \mathrm{ml}$ diluted medium was mixed with $2.2 \mathrm{ml}$ diluted biuret reagent and later with $0.1 \mathrm{ml}$ Folin and Ciocalteu's Phenol Reagent (Sigma) [34]. The color formed was read at a wavelength of $700 \mathrm{~nm}$. Protein concentrations were determined from a calibration curve.

\subsection{2. $L D H$ leakage}

LDH catalyzes the oxidation of lactate to pyruvate with simultaneous reduction of nicotinamide adenine dinucleotide (NAD) resulting in an increase in absorbance at $340 \mathrm{~nm}$. Schwann cell injury was quantitatively assessed by the measurement of LDH released from damaged or destroyed cells, in the extracellular fluid. Ten microliters of aliquots of the medium was mixed with $200 \mu \mathrm{LDH}$ reagent (Sigma). LDH activity was calculated by measuring the increase in absorbance at $340 \mathrm{~nm}$, as described previously [35].

\subsubsection{MTT assay}

The 3-(4,5-dimethylthiazol-2-yl)-2.5-diphenyl tetrazolium bromide (MTT, Sigma) was prepared as $0.5 \mathrm{mg} / \mathrm{ml}$ stock solution in PBS [36]. MTT $(0.35 \mathrm{ml})$ was added to each well and plates were incubated for $4 \mathrm{~h}$ at $37^{\circ} \mathrm{C}$. After incubation, the medium was aspirated and the formazan reaction products were dissolved in $100 \mu \mathrm{l}$ $0.04 \mathrm{~N} \mathrm{HCl} / \mathrm{EtOH}$. The optical density of the formazan solution was measured on an ELISA plate reader (Labsystems Multiscan RC) at $570 \mathrm{~nm}$.

\subsection{Statistical analysis}

In this study, all experiments were performed in a paired pattern and replicated 10 times. The differences between various tested conditions were evaluated by the paired $t$-test. The level of statistical significance is defined as $p<0.05$. 


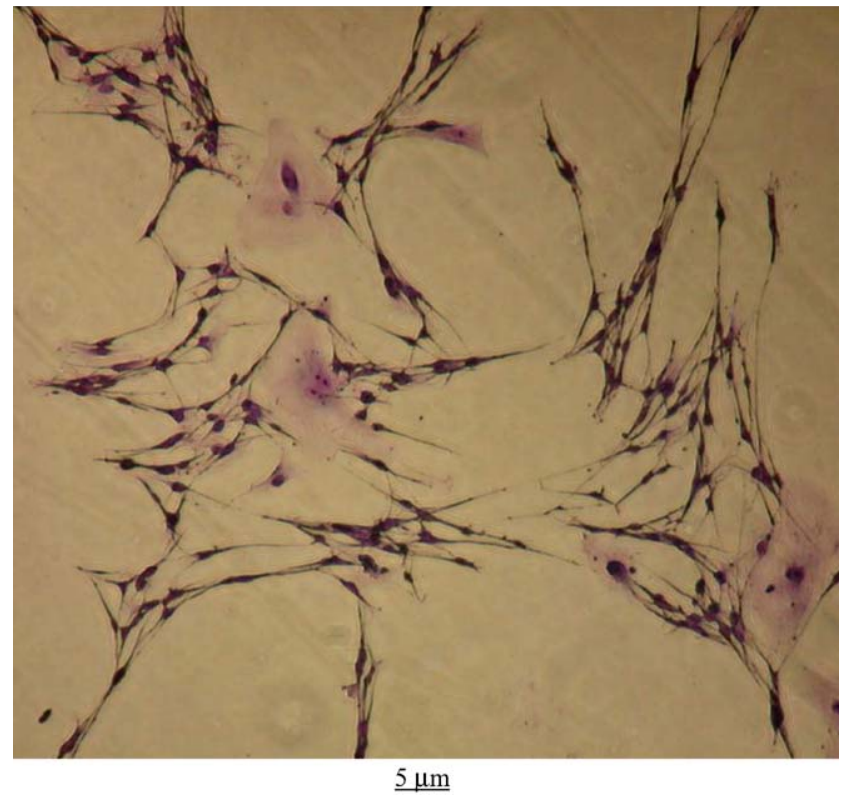

Fig. 2. The optical microscopic examination of the Schwann cell cultured in the control group $(100 \times)$. The Schwann cell adhered and extended processes well on the Petri dish.

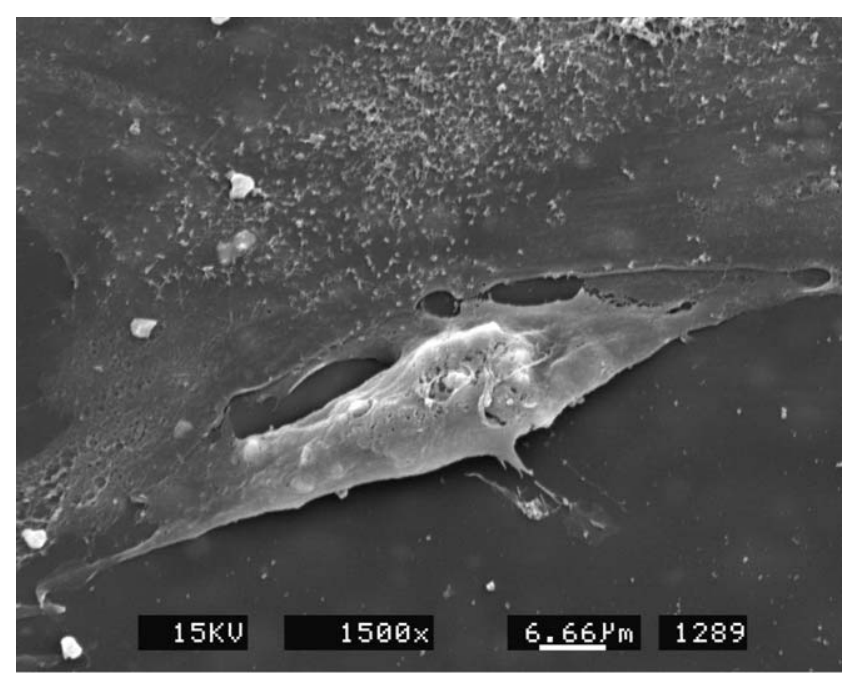

Fig. 3. Scanning electron micrographs of Scwann cells attached and adhered to the surface of GEN composite after 7 days in culture. The cells adhered and extended processes well on the membrane.

\section{Results and discussions}

\subsection{Morphological analysis}

Cell morphology on the different types of material surfaces was usually used to determine the cytocompatibility of materials [37,38]. The whole process of adhesion and spreading consists of cell attachment, filopodial growth, cytoplasmic webbing, and flattening of the cell mass was in a sequential fashion [39]. The effect of the various membranes on Schwann cell culture was observed under the optical microscope and SEM in this study. Fig. 2 shows the morphology of the Schwann cells cultured in the control group. The cells adhered and extended processes well on the Petri dish. In addition, SEM confirmed the presence of the Schwann cells on the GEN membranes throughout the 7 days of culture. Schwann cells on GEN composites showed morphologically indistinguishable from cells plated on control dishes (Fig. 3). SEM examination also revealed that the Schwann cells flattened and extended processes in a sequential fashion as cultured for 1,3 , and $7 \mathrm{~d}$.

\subsection{Biocompatibility tests}

The effects of different composite membranes on Schwann cell growth, as monitored by total cell protein, were shown in Fig. 4. Fig. 4 showed the effects of various membranes on the protein content of Schwann cells after 1, 3, 7 days of culture. GTG membrane with NGF immobilized by carbodiimide had constantly significant effects on Schwann cell protein content since the second day after plating. When GTG was used for Schwann cell culture with or without NGF solution soaking, it markedly decreased the cell protein content even in comparison with the control group. This result may indicate more cell attachment on GEN membrane since the protein content is higher from the second day after plating. In contrast, without immobilization of NGF, GTG membrane may even show less favorable surfaces for the attachment and growth of Schwann cells. Besides, the rate of increment in total protein content did not suggest NGF-immobilized GTG composite different from other groups. This observation

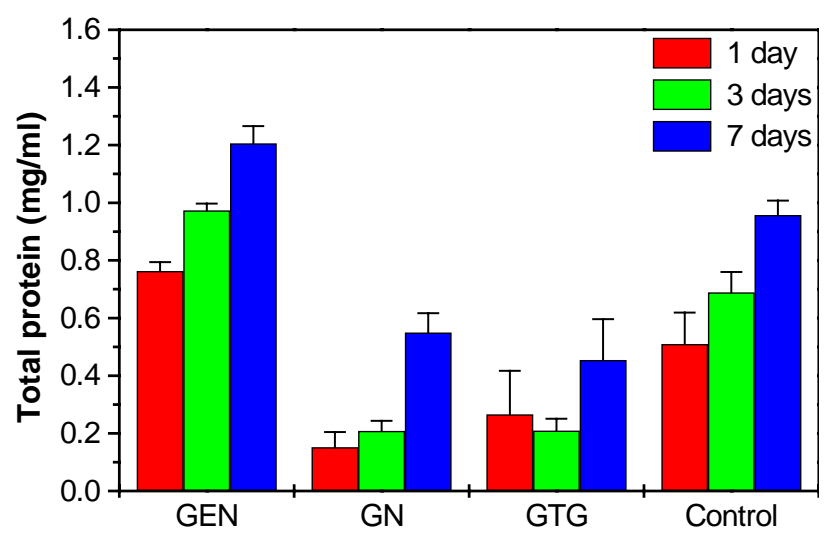

Fig. 4. Total cell protein test. It showed the effects of various membranes on the protein content of Schwann cells after 1, 3, 7 days of culture. GEN group had constantly significant effect on cell protein content since the second day after plating. GN and GTG groups markedly decreased the cell protein content even in comparison with the control group. 


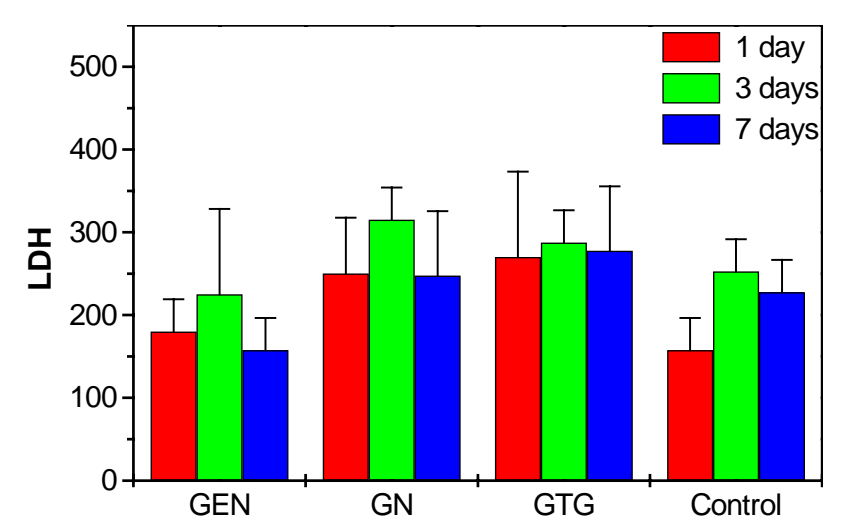

Fig. 5. LDH release test. A stable release of LDH in GTG/GN group but in a lower level in comparison with GEN/control group was noted. However, the differences in LDH leakage were not statistically significant among all the 4 groups and LDH concentration had not increased significantly from day 1 to day 7 .

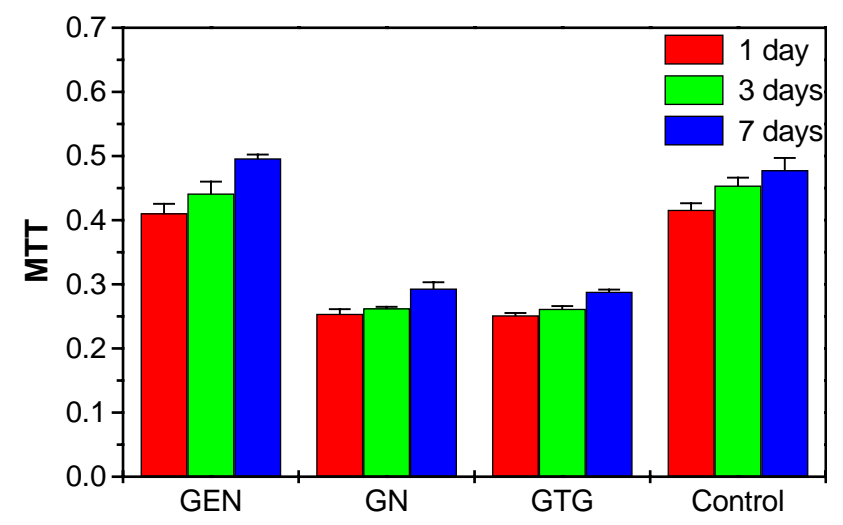

Fig. 6. MTT-tetrazolium assay. Schwann cells on the GEN membrane exhibited significantly higher total MTT reduction activity in comparison to other groups since the first day. However, for GN and GTG membrane, the MTT reduction activity of Schwann cells indicated a lower level than that on the GEN and control group.

suggests that NGF modification did not exponentially promote the growth of Schwann cells on GTG membranes.

As an intracellular enzyme, LDH was released only when cellular injury occurred. The release of LDH into culture medium provides an accurate and sensitive marker of cellular cytotoxicity in biocompatibility testing [40]. Therefore, the toxic effect of GEN/GTG composites on the cultured cells was determined by measuring the release of $\mathrm{LDH}$ into the culture medium. As shown in Fig. 5, a stable release of LDH in GTG/GN group but in a lower level in comparison with GEN/ control group was noted. However, the differences in LDH leakage were not statistically significant among all the 4 groups and LDH concentration had not increased significantly from day 1 to day 7 . This means that GTG composite, whether cross-linked with NGF or not, has little cytotoxic effect.

The time course of Schwann cell MTT reduction activity on various membranes in each experimental group is shown in Fig. 6. The reduction of MTT mainly occurs in the mitochondria through the action of succinate dehydrogenase, therefore providing a measure of mitochondria function [41]. Schwann cells on the GEN membrane exhibited significantly higher total MTT reduction activity in comparison to other groups since the first day. Similar to the result of protein content test, there was not a rapid increasing phase of MTT reduction activity from day 1 to day 7 and the increment of MTT reduction activity in GEN group was not significantly higher than other groups. However, for GN and GTG membrane, the MTT reduction activity of Schwann cells indicated a lower level than that on the GEN and control group.

Overall, LDH assay indicates that GTG is not cytotoxic to Schwann cells. We believe that cross-linked gelatin membrane treated with glycine aqueous solution to block non-reacted aldehyde groups is important to reduce the cytotoxicity. When carbodiimide was used to immobilize NGF onto GTG membrane, the procedures do not alter the cytotoxicity of GTG membrane. The result of MTT assay also supports these observations. Comparing the protein content and MTT assay among GEN, GN composite and control group, the data confirmed more attachment of Schwann cells on the GEN composite. Thus, it indicates that the procedure used in this study to immobilize NGF onto GTG membrane is reliable. However, the time course of MTT and protein content test does not suggest that GTG grafted with NGF promote the proliferation of Schwann cells. This result is compatible with previous researches. NGF has been reported to exert no effect on new born rat Schwann cell proliferation $[42,43]$. In vitro, the addition of NGF into the culture medium does not alter the cell cycle nor cell morphology of Schwann cells [44]. It is not clear why NGF immobilization improves the attachment of Schwann cells on the GTG composite. However, there has been evidence suggesting that cell adhesion molecule expression on Schwnn cells can be directly regulated by NGF [45]. This may partially explain the higher protein content and MTT reduction activity on GEN membranes.

In the GN group, NGF soaking procedure did not alter the attachment and growth of Schwann cells on the GTG membrane. Previously, several reports support the idea that neurotrophic factor treatment of a tubular implant facilitates nerve regeneration. With these procedures, similarly, neurotrophic factor is not covalently coupled to the surface of the biodegradable material, leaving open the possibility that neurotrophic factors desorb into solution, with the remaining concentration rapidly decreasing. From our approach, 
because GTG is a biodegradable material and NGF is immobilized on to GTG covalently, the proposed mechanisms of NGF cross-linking is shown in Fig. 1. Although the release characteristics of NGF from GEN was not investigated directly in this work, the initial release of NGF could de due to hydrolysis of loosely bonded NGF. Possibly in a lower rate, covalently immobilized NGF can be released during degradation of the GEN composites. And we believe this mechanism could contribute to the sustained release of NGF. To prove the effect of NGF on neurite regeneration directly, we are now investigating the effects of various composites (GTG, GEN, GEN with cultured Schwann cells) on PC12 cells. The differentiation would be important to evaluate whether NGF or/and Schwann cells on GTG membrane promote the growth of neural cells. Furthermore, with the presence of Schwann cells, GEN membrane incorporating both cellular and acellular elements will be beneficial for axonal regeneration in peripheral nerve injury.

\section{Conclusion}

We report here the result of an effort to immobilize NGF onto the GTG membrane by using carbodiimide. The experiments carried out on the effect of NGF grafted onto GTG membranes indicate that the procedure used in immobilization of NGF onto GTG membrane may be beneficial for adhesion of Schwann cells on the membranes. Another finding of this study is the feasibility of culturing Schwann cells on GEN and GTG membranes. None of the materials (GEN/GN/ GTG) appeared to cause any alteration in Schwann cell morphology. Without immobilization of NGF on the surfaces, GTG membrane still showed cytocompatibility with Schwann cells. With the techniques used in this study, we will be able to design a tissue-engineered biodegradable material that incorporates with Schwann cells and covalently immobilized NGF. During the degradation of GEN composite, there is the potential for sustained release of NGF. Therefore, it is reasonable to make use of GEN membrane to improve axonal regeneration of injured peripheral nerve. A thorough study of the effects of Schwann cell seeded GEN membrane on the growth of neurons and animal experiments will be followed in the future.

\section{References}

[1] Mackinnon SE, Dellon AL. Clinical nerve reconstruction with a bioabsorbable polyglycolic acid tube. Plast Reconstr Surg 1990;85(3):419-24.

[2] Evans PJ, Mackinnon SE, Levi AD, Wade JA, Hunter DA, Nakao Y, Midha R. Cold preserved nerve allografts: changes in basement membrane, viability, immunogenicity, and regeneration. Muscle Nerve 1998;21(11):1507-22.

[3] Nicoli Aldini N, Perego G, Cella GD, Maltarello MC, Fini M, Rocca M, Giardino R. Effectiveness of a bioabsorbable conduit in the repair of peripheral nerves. Biomaterials 1996; 17(10):959-62.

[4] Archibald SJ, Krarup C, Shefner J, Li ST, Madison RD. A collagen-based nerve guide conduit for peripheral nerve repair: an electrophysiological study of nerve regeneration in rodents and nonhuman primates. J Comp Neurol 1991;306(4):685-96.

[5] Archibald SJ, Shefner J, Krarup C, Madison RD. Monkey median nerve repaired by nerve graft or collagen nerve guide tube. J Neurosci Part 2 1995;15(5):4109-23.

[6] Den Dunnen WFA, Schakenraad GJ, Zondervan AJ, Pennings B, Lei VD, Robinson PH. A new PLLA/PCL copolymer for nerve regeneration. J Mater Sci: Mater Med 1993;4:521-5.

[7] Robinson PH, van der Lei B, Hoppen HJ, Leenslag JW, Pennings AJ, Nieuwenhuis P. Nerve regeneration through a two-ply biodegradable nerve guide in the rat and the influence of ACTH4-9 nerve growth factor. Microsurgery 1991;12(6):412-9.

[8] Tountas CP, Bergman RA, Lewis TW, Stone HE, Pyrek JD, Mendenhall HV. A comparison of peripheral nerve repair using an absorbable tubulization device and conventional suture in primates. J Appl Biomater 1993;4(3):261-8.

[9] Merle M, Dellon AL, Campbell JN, Chang PS. Complications from silicon-polymer intubulation of nerves. Microsurgery 1989;10(2):130-3.

[10] Madison R, da Silva CF, Dikkes P, Chiu TH, Sidman RL. Increased rate of peripheral nerve regeneration using bioresorbable nerve guides and a laminin-containing gel. Exp Neurol 1985;88(3):767-72.

[11] Evans GR, Brandt K, Widmer MS, Lu L, Meszlenyi RK, Gupta PK, Mikos AG, Hodges J, Williams J, Gurlek A, Nabawi A, Lohman R, Patrick Jr. CW. In vivo evaluation of poly(L-lactic acid) porous conduits for peripheral nerve regeneration. Biomaterials 1999;20(12):1109-15.

[12] Agrawal CM, Athanasiou KA. Technique to control $\mathrm{pH}$ in vicinity of biodegrading PLA-PGA implants. J Biomed Mater Res 1997;38(2):105-14.

[13] Suganuma J, Alexander H. Biological response of intramedullary bone to poly L-lactic acid. J Appl Biomater 1993;4:13-27.

[14] Colin W, Donoff RB. Nerve regeneration through collagen tubes. J Dent Res 1984;63(7):987-93.

[15] Itoh S, Takakuda K, Kawabata S, Aso Y, Kasai K, Itoh H, Shinomiya K. Evaluation of cross-linking procedures of collagen tubes used in peripheral nerve repair. Biomaterials 2002;23(23): 4475-81.

[16] Peppas NA. In: Ratner B, editor. Biomaterials science. New York: Academic Press; 1996. p. 63.

[17] Big A, Cojazzi G, Panzavolta S, Rubini K, Roveri N. Mechanical and thermal properties of gelatin films at different degrees of glutaraldehyde crosslinking. Biomaterials 2001;22(8):763-8.

[18] Rich KM, Alexander TD, Pryor JC, Hollowell JP. Nerve growth factor enhances regeneration through silicone chambers. Exp Neurol 1989;105(2):162-70.

[19] He C, Chen Z. Enhancement of motor nerve regeneration by nerve growth factor. Microsurgery 1992;13(3):151-4.

[20] Whitworth IH, Brown RA, Dore CJ, Anand P, Green CJ, Terenghi G. Nerve growth factor enhances nerve regeneration through fibronectin grafts. J Hand Surg [Br] 1996;21(4):514-22.

[21] Fine EG, Decosterd I, Papaloizos M, Zurn AD, Aebischer P. GDNF and NGF released by synthetic guidance channels support sciatic nerve regeneration across a long gap. Eur J Neurosci 2002;15(4):589-601.

[22] Hanthamrongwit M, Reid WH, Grant MH. Chondroitin-6sulphate incorporated into collagen gels for the growth of human 
keratinocytes: the effect of cross-linking agents and diamines. Biomaterials 1996;17(8):775-80.

[23] Laemmel E, Penhoat J, Warocquier-Clerout R, Sigot-Luizard MF. Heparin immobilized on proteins usable for arterial prosthesis coating: growth inhibition of smooth-muscle cells. J Biomed Mater Res 1998;39(3):446-52.

[24] Pieper JS, Oosterhof A, Dijkstra PJ, Veerkamp JH, van Kuppevelt TH. Preparation and characterization of porous crosslinked collagenous matrices containing bioavailable chondroitin sulphate. Biomaterials 1999;20(9):847-58.

[25] Lin FH, Dong GC, Chen KS, Jiang GJ, Huang CW, Sun JS. Immobilization of Chinese herbal medicine onto the surfacemodified calcium hydrogenphosphate. Biomaterials 2003;24(13): 2413-22.

[26] Brown RE, Erdmann D, Lyons SF, Suchy H. The use of cultured Schwann cells in nerve repair in a rabbit hind-limb model. J Reconstr Microsurg 1996;12(3):149-52.

[27] Guenard V, Kleitman N, Morrissey TK, Bunge RP, Aebischer P. Syngeneic Schwann cells derived from adult nerves seeded in semipermeable guidance channels enhance peripheral nerve regeneration. J Neurosci 1992;12(9):3310-20.

[28] Heath CA, Rutkowski GE. The development of bioartificial nerve grafts for peripheral-nerve regeneration. Trends Biotechnol 1998; 16(4):163-8.

[29] Keeley R, Sabelman E, Kadlcik P. Synthetic nerve graft containing collagen and syngeneic Schwann cells improves functional, electrophysiological and histological parameters of peripheral nerve regeneration. Restorative Neurol Neurosci 1993;5:353-66.

[30] Levi AD, Guenard V, Aebischer P, Bunge RP. The functional characteristics of Schwann cells cultured from human peripheral nerve after transplantation into a ap within the rat sciatic nerve. J Neurosci Part 1 1994;14(3):1309-19.

[31] Anuforo DC, Acosta D, Smith RV. Hepatotoxicity studies with primary cultures of rat liver cells. In Vitro 1978;14(12):981-8 (No abstract available).

[32] Sgouras D, Duncan R. Methods for the evaluation of biocompatibility of soluble synthetic polymers which have potential for biomedical use. 1. Use of the tetrazolium-based colorimetric assay as a preliminary screen for evaluation of in vitro cytotoxicity. J Mater Sci: Mater Med 1990;1:61-8.
[33] Brockes JP, Fields KL, Raff MC. Studies on cultured rat Schwann cells. I. Establishment of purified populations from cultures of peripheral nerve. Brain Res 1979;165(1):105-18.

[34] Ohnishi ST, Barr JK. A simplified method of quantitating protein using the biuret and phenol reagents. Anal Biochem 1978;86(1): 193-200.

[35] Amador E, Dorfman LE, Wacker WEC. Serum lactic dehydrogenase: an analytical assessment of current assays. Clin Chem 1963;9:391.

[36] Mosmann T. Rapid colorimetric assay for cellular growth and survival: application to proliferation and cytotoxicity assays. J Immunol Methods 1983;65(1-2):55-63.

[37] Hunter A, Archer CW, Walker PS, Blunn GW. Attachment and proliferation of osteoblasts and fibroblasts on biomaterials for orthopaedic use. Biomaterials 1995;16(4):287-95.

[38] Bagambisa FB, Joos U. Preliminary studies on the phenomenological behaviour of osteoblasts cultured on hydroxyapatite ceramics. Biomaterials 1990;11(1):50-6.

[39] Rajaraman R, Rounds DE, Yen SP, Rembaum A. A scanning electron microscope study of cell adhesion and spreading in vitro. Exp Cell Res 1974;88(2):327-39.

[40] Rae T. A study on the effects of particulate metals of orthopaedic interest on murine macrophages in vitro. J Bone Jt Surg $\mathrm{Br}$ 1975;57(4):444-50.

[41] Slater TF, Sawyer B, Struli U. Studies on succinate-tetrazolium reductase system III, points of coupling of four different tetrazolium salts. Biochim Biophys Acta 1963;77:383-93.

[42] Taniuchi M, Clark HB, Johnson Jr. EM. Induction of nerve growth factor receptor in Schwann cells after axotomy. Proc Natl Acad Sci USA 1986;83(11):4094-8.

[43] Ridley AJ, Davis JB, Stroobant P, Land H. Transforming growth factors-beta 1 and beta 2 are mitogens for rat Schwann cells. J Cell Biol Part 2 1989;109(6):3419-24.

[44] Bosch EP, Zhong W, Lim R. Axonal signals regulate expression of glia maturation factor-beta in Schwann cells: an immunohistochemical study of injured sciatic nerves and cultured Schwann cells. J Neurosci 1989;9(10):3690-8.

[45] Seilheimer B, Schachner M. Regulation of neural cell adhesion molecule expression on cultured mouse Schwann cells by nerve growth factor. EMBO J 1987;6(6):1611-6. 